\title{
Correction of protruded incisors by rapid tooth distalization and skeletal anchorage systems: Orthodontic treatment of an adult patient
}

\author{
Şeniz Karaçay (*), Ersin Yıldırım (*), Osman Bengi (**), Kerim Ortakoğlu (***)
}

\begin{abstract}
Rapid canine distalization through periodontal ligament distraction is an efficient method to shorten the treatment duration in premolar extraction cases. After distalization phase, skeletal anchorage systems can be used during the retraction of the incisors in patients required maximum anchorage.

A 37 years old female patient with convex profile and prominent lips referred to our clinic for orthodontic treatment. The chief complaints were her unaesthetic facial appearance, and difficulties in closing her lips and pronunciation of some words. To retract the protruded incisors, extraction of the mandibular first premolars, and using the space of the previously extracted maxillary right second premolar and left first premolar was planned. In order to shorten the duration of treatment, rapid tooth distalization through the periodontal distraction was used and to provide maximum anchorage control skeletal anchors were preferred. At the end of the orthodontic treatment that lasted for 11 months, prominence of the upper and lower lips, and the convex profile were corrected through the retrusion of incisors and the patient acquired a more youthful appearance.
\end{abstract}

Key words: Rapid canin distalization, Periodontal ligament distraction, Maksimum anchorage

ÖZET

Hızlı diş distalizasyonu ve iskeletsel ankraj sistemleri ile protrüze kesici dişlerin düzeltilmesi: Yetişkin bir hastanın ortodontik tedavisi Periodontal ligament distraksiyonu aracılığı ile hızlı kanin distalizasyonu, premolar çekimli vakaların tedavi sürelerini kısaltmak için etkili bir yöntemdir. Maksimum ankraj intiyacı olan hastalarda, distalizasyon aşamasından sonra kesici retraksiyonu sırasında iskeletsel ankraj sistemleri kullanılabilir. Konveks profili ve belirgin dudakları olan, 37 yaşındaki bayan hasta ortodontik tedavi için kliniğimize başvurdu. Hastanın esas şikâyetleri estetik olmayan yüz görüntüsü, ve dudaklarını kapatmakta ve bazı kelimelerin telaffuzunda zorlanmasıydı. Protrüze kesici dişleri retrakte edebilmek için mandibular birinci premoların çekimi ve daha önce çekilmiş olan maksiller sağ ikinci premolar ile sol birinci premolar dişlerin çekim boşluklarının kullanııması planlanmıştır. Tedavi süresini kısaltmak için periodontal ligament distraksiyonu aracıığı ile hızlı diş distalizasyonu yöntemi kullanılmış ve maksimum ankraj kontrolü sağlamak için iskeletsel ankrajlar tercih edilmiş̧ir. 11 ay süren ortodontik tedavi sonunda kesici retraksiyonu ile alt ve üst dudakların belirginliği ve konvex profil düzelmiş, hasta daha genç bir görünüme kavuşmuştur.

Anahtar kelimeler: Hızlı kanin distalizasyonu, Periodontal ligament distraksiyonu, Maksimum ankraj

\footnotetext{
* GATA Haydarpaşa Eğt. Hast., Dişhek. Servisi, Ortodonti Bölümü

** GATA Dişhek. Bil. Merk., Ortodonti AD. Bşk.

*** Medicana Diş Hastanesi

Reprint request: Doç. Dr. Şeniz Karaçay, GATA Haydarpaşa Eğt. Hast., Dişhekimliği Servisi, Ortodonti Bölüm şefi, Üsküdar/Istanbul

E-mail: skaracay@gata.edu.tr
}

Date submitted: January 16, 2012 Date accepted: January 19, 2012 Online publication date: September 26, 2013

\section{Introduction}

Orthodontic treatments involve limited modalities after the completion of the growth period and usually camouflage treatment is required by extraction of two or four premolar teeth for adults. In the tooth extraction cases, anchorage control is one of the most important cornerstones of the treatment. In some cases, the protrusion of the incisors is so severe that $100 \%$ anchorage, which can be named as absolute anchorage, has to be maintained (1-3).

Recently, clinicians have developed skeletal anchorage systems since extraoral appliances affect patient cooperation negatively and usually are rejected by adults because of social reasons. Traditional endosseous implants, midpalatal endosseous implants, miniscrews, and miniplates have been used by various authors to achieve absolute anchorage and satisfactory results have been reported (1-10). Zygomatic anchor is a titanium miniplate placed in the zygomatic area to provide skeletal anchorage and this system has been used in the treatment of skeletal openbite and for the retraction of incisors by various researchers (10-15).

Conventional orthodontic treatments with either fixed or functional appliances rely on remodeling of the alveolar bone and require a certain time. In adults orthodontic treatment duration may lengthen due to the biology and histology of the bone. However, elongation of the treatment time usually affects the patient's cooperation negatively. Rapid orthodontic approaches are important especially from the aspect of adults and various researchers have been studied to decrease the orthodontic treatment time. Rapid canine distalization through periodontal distraction is one of the efficient methods to shorten the duration 
of treatment in premolar extraction cases $(15,16)$. After Liou and Huang (16) have shown that rapid orthodontic tooth movement can be obtained by transversal distraction of the periodontal ligament, various researchers reported successful results with this technique $(15,17-21)$.

In this case report, orthodontic treatment of an adult who had severe bimaxillary protruded incisors was presented. Rapid tooth distalization through periodontal distraction was performed to shorten the duration of treatment and skeletal anchorage systems were applied to provide maximum anchorage control during the retraction of maxillary and mandibular incisors.

\section{Case report}

A 37-year old female patient was referred to the Department of Orthodontics with the complaints of unaesthetic facial appearance and difficulties in closing her lips. Extra oral examination revealed a convex profile with prominent and protruded lips. The patient had difficulties in closing her lips and pronunciation of some words. In the intraoral examination, it was observed that maxillary right second premolar and left first premolar teeth had been extracted before. Maxillary and mandibular incisors were protruded with diastema in-between upper anterior teeth. The patient had an overjet of 9 mm (Fig. 1)

The treatment plan consisted of extraction of the lower first premolars and using the space of the previously extracted maxillary right second

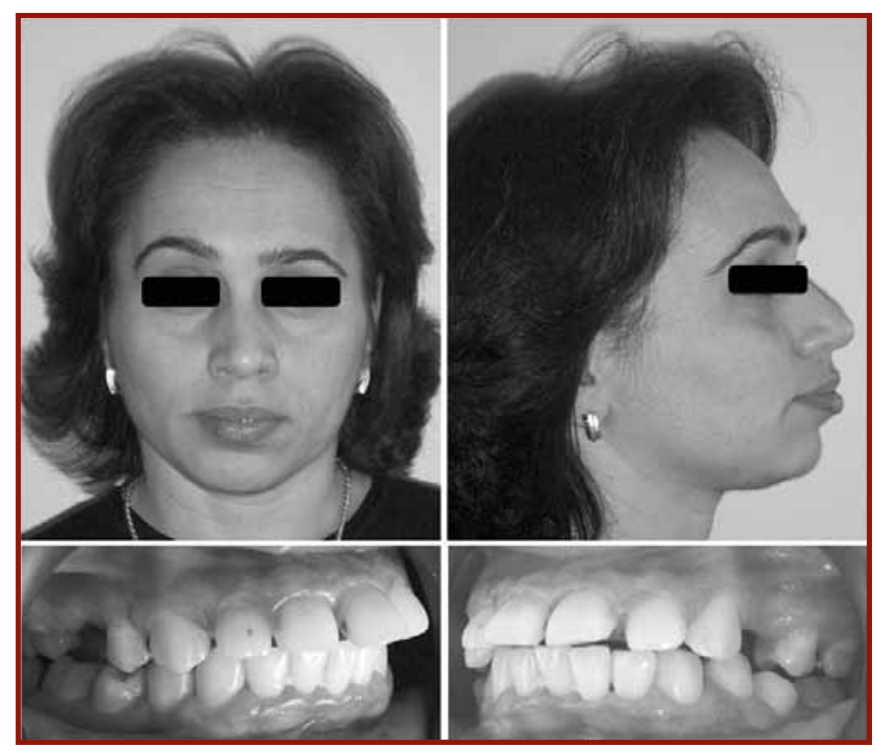

Figure 1. Extraoral and intraoral photograph of the patient before treatment premolar and left first premolar. In order to shorten the duration of treatment, rapid tooth distalization through the periodontal distraction and skeletal anchors to provide maximum anchorage control was planned. Following the extraction of the lower first premolars, vertical osteotomies were carried out at the buccaly and lingual sites of the interseptal bone adjacent to the canine tooth. The vertical osteotomies were connected with an oblique osteotomy extended toward the base of the interseptal bone to weaken the resistance. After the surgical approach, the distractors constructed in our department were cemented on the lower canines and molar teeth. The distractors were activated two times a day with 12 hours intervals. Three weeks later, the canines were distracted to the place of extracted first premolars. After the distraction of lower canines, distraction of maxillary right first premolar and left canine began. Two artificial sockets were prepared in the right maxillary second premolar and left maxillary first premolar regions. The same surgical procedure was performed in the operation site as if there was a natural extraction socket and the related teeth were distracted by activating the distraction device twice a day. After these teeth were distalized to the desired position in six weeks, zygoma anchors were attached to the zygomatic buttress and mini plates were attached to the mandible to provide maximum anchorage during retraction of the incisors (Fig. 2).

At the end of orthodontic treatment of 11 months, Class I molar and canine relationship was achieved, the diastema between the anterior teeth was closed, and the severely protruded incisors were retracted. Prominence of the upper and lower lips, and the convex profile were also corrected through the retrusion of incisors and the patient acquired a more youthful appearance (Fig. 3). Pre- and post-treatment cephalometric measurements are presented at table

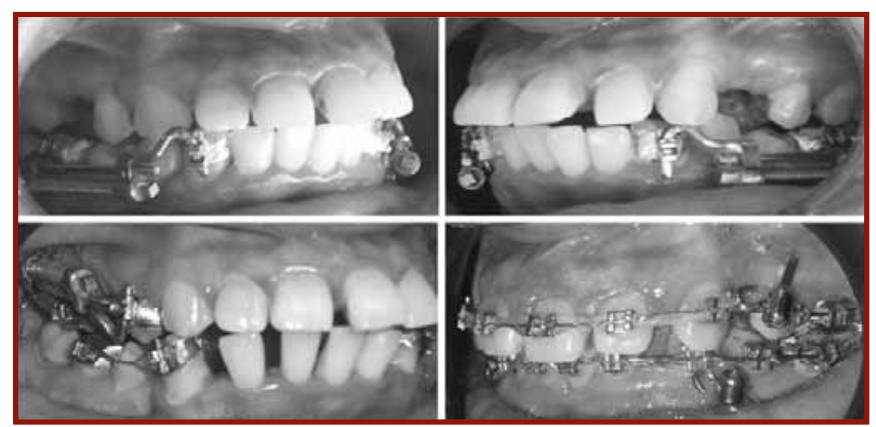

Figure 2. Rapid canin distalizaiton and use of skeletal anchors during the leveling phase and retraction of incisors 
I and superimpositions of the cephalograms are presented at figure 4 . Pronunciation of the patient was improved and opening of the lips during rest position was eliminated. The patient was extremely pleased with these dramatic changes.

\section{Discussion}

In the presented, case rapid tooth distalization and skeletal anchors were used to decrease the duration of treatment and to reinforce the anchorage of the posterior segment. The treatment period lasted 11 months. In our previous case report, treatment was completed in six months with this system (15). The elongation of the treatment time in the presented case depends on the severe protrusion of the incisors

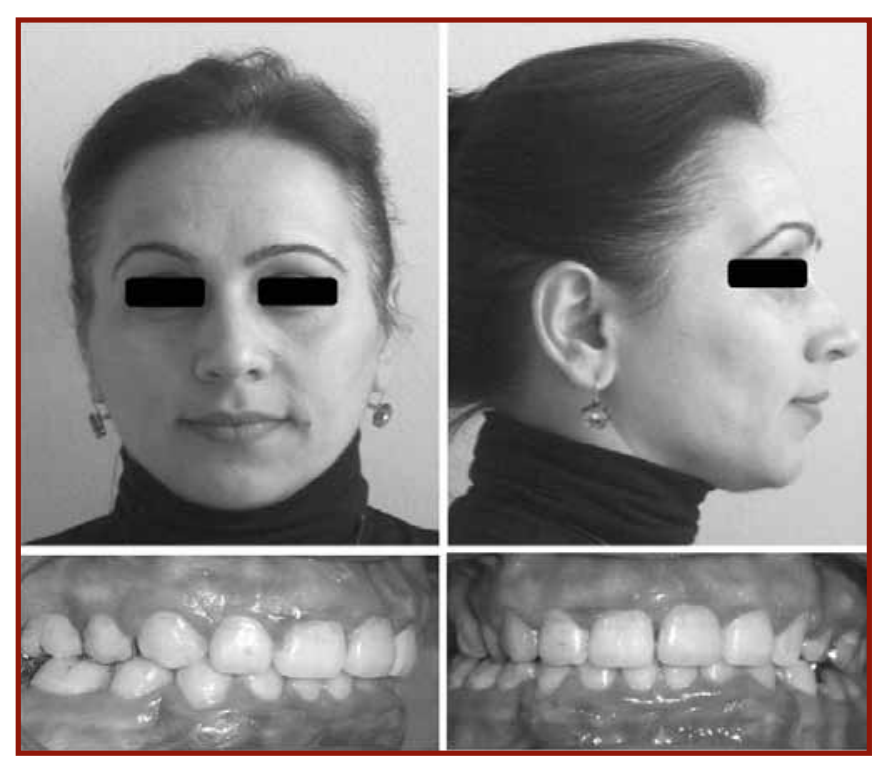

Figure 3. Extraoral and intraoral photograph of the patient after treatment

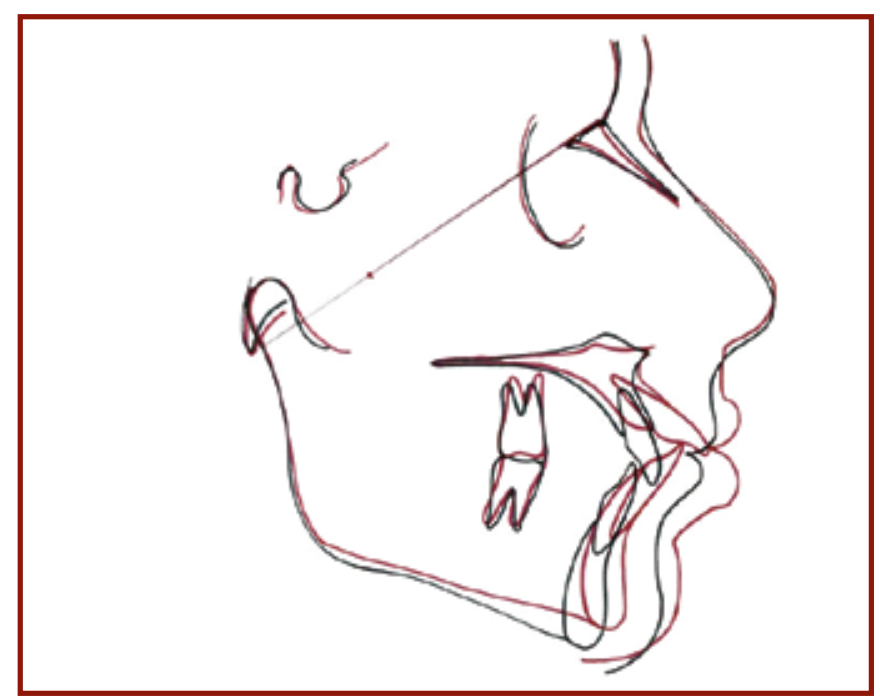

Figure 4. Superimpositions of the cephalograms taken before treatment (TO-red line) and after treatment (T1-black line)

\begin{tabular}{lcc} 
Table I. Pre-and post-treatment cephalometric measurements \\
\hline & Pre-treatment (TO) & Post-treatment (T1) \\
SNA & $84^{\circ}$ & $82^{\circ}$ \\
SNB & $79^{\circ}$ & $76^{\circ}$ \\
ANB & $5^{\circ}$ & $6^{\circ}$ \\
NV-A & $5 \mathrm{~mm}$ & $3 \mathrm{~mm}$ \\
NV-Pog & $-1 \mathrm{~mm}$ & $-7 \mathrm{~mm}$ \\
S-N & $71 \mathrm{~mm}$ & $71 \mathrm{~mm}$ \\
S & $126^{\circ}$ & $126^{\circ}$ \\
Ar & $143^{\circ}$ & $139^{\circ}$ \\
Go & $123^{\circ}$ & $126^{\circ}$ \\
Ar-Go & $50 \mathrm{~mm}$ & $52 \mathrm{~mm}$ \\
Go-Gn & $75 \mathrm{~mm}$ & $73 \mathrm{~mm}$ \\
Y Axis & $68^{\circ}$ & $72^{\circ}$ \\
SN/ANS-PNS & $9^{\circ}$ & $10^{\circ}$ \\
SN/OcC. & $11^{\circ}$ & $21^{\circ}$ \\
SN/Go-Gn & $29^{\circ}$ & $34^{\circ}$ \\
ANS-PNS/Go-Gn & $20^{\circ}$ & $21^{\circ}$ \\
N-Me & $123^{\circ}$ & $128^{\circ}$ \\
N-ANS & $55^{\circ}$ & $56^{\circ}$ \\
ANS-Me & $69^{\circ}$ & $74^{\circ}$ \\
U1/SN & $126^{\circ}$ & $97^{\circ}$ \\
L1/Go-Gn & $111^{\circ}$ & $96^{\circ}$ \\
U1/L1 & $94^{\circ}$ & $140^{\circ}$ \\
U1/NA & $43^{\circ}$ & $13^{\circ}$ \\
U1-NA & $13 \mathrm{~mm}$ & $3 \mathrm{~mm}$ \\
L1/NB & $39^{\circ}$ & $23^{\circ}$ \\
L1-NB & $15 \mathrm{~mm}$ & $5 \mathrm{~mm}$ \\
E-Line (UL/LL) & $\mathrm{mm} / 5 \mathrm{~mm}$ & $4 \mathrm{~mm}$ \\
Overjet & $9 \mathrm{~mm}$ \\
\hline & & $\mathrm{mm}$ \\
\hline & & \\
\hline
\end{tabular}

as incisor retraction period took rather a long time. Additionally, rapid distalization of the upper right first premolar and left canine lasted six weeks although lower canine were distalized in three weeks. In the mandible, rapid distalization of the canines began just after the extraction of the lower first premolars. However, in the maxilla the right second premolar and left first premolar were extracted previously so an artificial socket was created initially and then corticotomy was performed to obtain rapid tooth movement. Tooth movement was not as fast as expected in the artificial socket. Anyway, 11 months was a short treatment period for the orthodontic treatment of this patient, and acceptable occlusion and profile were achieved at the end of treatment.

The philosophy and the healing process of rapid tooth movement through periodontal distraction are like those in Rapid Palatal Expansion and usually the incisors are partially moved distally through the stretched transseptal ligaments $(15,16)$. In the 
presented case, during the diastalization period of the canines, incisors were also retracted moderately. A consolidation period of minimum 2 months is required for reorganization of the new bone at the mesial side of the distalized tooth. During this retention period, forces with mesial vectors would cause anchorage loss of the posterior segment so skeletal anchors were placed and posterior teeth were ligatured to these units in order to reinforce the anchorage of posterior teeth during consolidation period. In this combined technique, miniscrews have a great risk of failure because of the callus formation in the distraction side and immature bone during consolidation period. Zygoma anchorage system is more reliable to be used combined with tooth distraction as it is performed to zygomaticomaxillary buttress in the maxilla and to the base of the corpus in the mandible as far as possible to the root of the distracted tooth $(13,15)$ In the posterior of maxilla, miniscrews have lower success rate as the buccal cortical bone is thinner than mandible and miniplates were reported to be more reliable (22).

In the presented case, correction of the protruded incisors changed the appearance of the patient dramatically and she gained a more youthful appearance. At the beginning of the orthodontic treatment the patient was embarrassed with her appearance, and she was depressive. However, at the end of treatment period it was observed that the patient was significantly more vivacious, communicative, and self confident.

\section{References}

1. Proffit WR. Biomechanics and mechanics. In: Proffit WR,Fields HW Jr, eds. Contemporary Orthodontics. St.Louis, Miss: Mosby; 2000:295-362.

2. Umemori M, Sugawara J, Mitani H, Nagasaka H, Kawamura H. Skeletal anchorage system for openbite correction. Am J Orthod Dentofac Orthop. 1999;115:116-174.

3. Ohmae M, Saito S, Morohashi T, et al. A clinical and histological evaluation of titanium mini-implants as anchors for orthodontic intrusion in the beagle dog. Am J Orthod Dentofac Orthop. 2001;119:489-497.

4. Wehrbein H, Glatzmaier J, Mundwiller U, Diedrich P. The orthodontic system: a new implant system for orthodontic anchorage in the palate. J Orofac Orthop. 1996;57:142-153.

5. Tosun T, Keles A, Erverdi N. Method for the placement of palatal implants. Int J Oral Maxillofac Implants. 2002;17:95-100.

6. Kawakami M, Miyawaki S, Noguchi H, Kirita T. Screwtype implants used as anchorage for lingual orthodontic mechanics: a case of bimaxillary protrusion with second premolar extraction. Angle Orthod. 2004;74:715-719.

7. Ohnishi H, Yagi T, Yasuda Y, Takada K. A mini-implant for orthodontic anchorage in a deep overbite case. Angle Orthod. 2005;75:444-452.

8. Chen C, Chang C, Hsieh C, Tseng Y, Shen Y, Huang I, Yang C, Chen C. The use of microimplants in orthodontic anchorage. J Oral Maxillofac Surg. 2006;64:1209-1213.

9. Sherwood KH, Burch JG. Skeletally based miniplate supported orthodontic anchorage. J Oral Maxillofac Surg. 2005; 63: 279-284.

10. Sherwood KH, Burch JG, Thomson WJ. Closing anterior open bites by intruding molars with titanium miniplate anchorage. Am J Orthod Dentofac Orthop. 2002;122:563-600.

11. Erverdi N, Tosun T, Keleş A. A new anchorage site for the treatment of anterior openbite: zygomatic anchorage. Case report. World J Orthod. 2002;3:147-153.

12. Erverdi N, Usumez S, Solak A. New generation open-bite treatment with zygomatic anchorage. Angle Orthod. 2006;76:519-526.

13. De Clerk H, Geerinckx V, Siciliano S. The zygoma anchorage system. J Clin Orthod. 2002;36:455-459.

14. Erverdi N, Acar A. Zygomatic anchorage for en masse retraction in the treatment of severe class II division I. Angle Orthod. 2005;75:483-490.

15. Bengi AO, Karacay S, Akin E, Olmez H, Okçu KM, Mermut S. Use of zygomatic anchors during rapid canine distalization: A preliminary case report. Angle Orthod. 2006;76:137-147.

16. Liou EJ, Huang S. Rapid canine retraction through distraction of periodontal ligament. Am J Orthod Dentofac Orthop. 1998;114:372-382.

17. Kişnişci RS, İşeri H, Tüz HH, Altuğ AT. Dentoalveolar distraction osteogenesis for rapid orthodontic canine retraction. Journal of Oral and Maxllofacial Surg. 2002;60:389-394.

18. Gurgan CA, Işeri H, Kisnisci R. Alterations in gingival dimensions following rapid canine retraction using dentoalveolar distraction osteogenesis. Eur J Orthod. 2005;27:324-332.

19. Karacay S, Saygun I, Bengi AO, Serdar M. Tumor Necrosis Factor- $\alpha$ levels during two different canine distalization techniques. Angle Orthod. 2007;1:142147.

20. Sukurica Y, Karaman A, Gürel HG, Dolanmaz D. Rapid canine distalization through segmental alveoler distraction osteogenesis. Angle Orthod. 2007;77:226236.

21. Kurt G, Iseri H, Kişnişçi R. Rapid tooth movement and orthodontic treatment using dentoalveoler distraction (DAD). Angle Orthod. 2010; 80:597-606.

22. Miyawaki S, Koyama I, Inoue M, Mishima K, Sugahara T, Yamamoto TT. Factors associated with the stability of titanium screws placed in the posterior region for orthodontic anchorage. Am J Orthod Dentofac Orthop. 2003;124:373-378. 